\title{
Over-the-scope clip is an effective therapy for postbanding ulcer bleeding after initially successful transjugular intrahepatic portosystemic shunt therapy
}

Postbanding ulcer bleeding (PBUB) is a potential deadly complication after esophageal variceal banding (EVB) in patients with portal hypertension, with a reported incidence of $2.6 \%-7.3 \%$ [1]. Various treatment possibilities for PBUB, such as cyanoacrylate injection, self-expandable metal stents, and transjugular intrahepatic portosystemic shunt (TIPS), are commonly applied. Rebleeding from a postbanding ulcer after initially successful TIPS is rare, and no clear treatment algorithm is available. Here, we report on the successful application of an over-the-scope clip (OTSC) to treat a PBUB after successful TIPS not amenable to EVB or hemoclip.

A 45-year-old man with a history of alcoholic liver cirrhosis (Child-Pugh stage B and model for end-stage liver disease score 6) underwent EVB and cyanoacrylate injection for bleeding esophageal varices at an external hospital. After recurrent drops in hemoglobin level, which was suspicious for intermittent refractory PBUB not visible on repeated esophagogastroduodenoscopy (EGD), he was referred to our unit for emergency TIPS.

The TIPS procedure was uneventful. Thereafter, he had another drop in hemoglobin level. Urgent EGD revealed a spurting PBUB ( Fig.1a). Tissue scarring meant that repeat EVB or hemoclipping was not possible. Thus, an OTSC was applied (Type 12/6T; Ovesco Medical, Tübingen, Germany) (\Fig.1 b). Hemostasis was achieved immediately ( $\mathbf{F i g . 1} \mathbf{c}$ ). Second-look endoscopy revealed stable hemostasis, and the hemoglobin level remained stable during the subsequent clinical course ( $\mathbf{F i g} . \mathbf{1} \mathbf{d}, \triangleright$ Video 1 ).

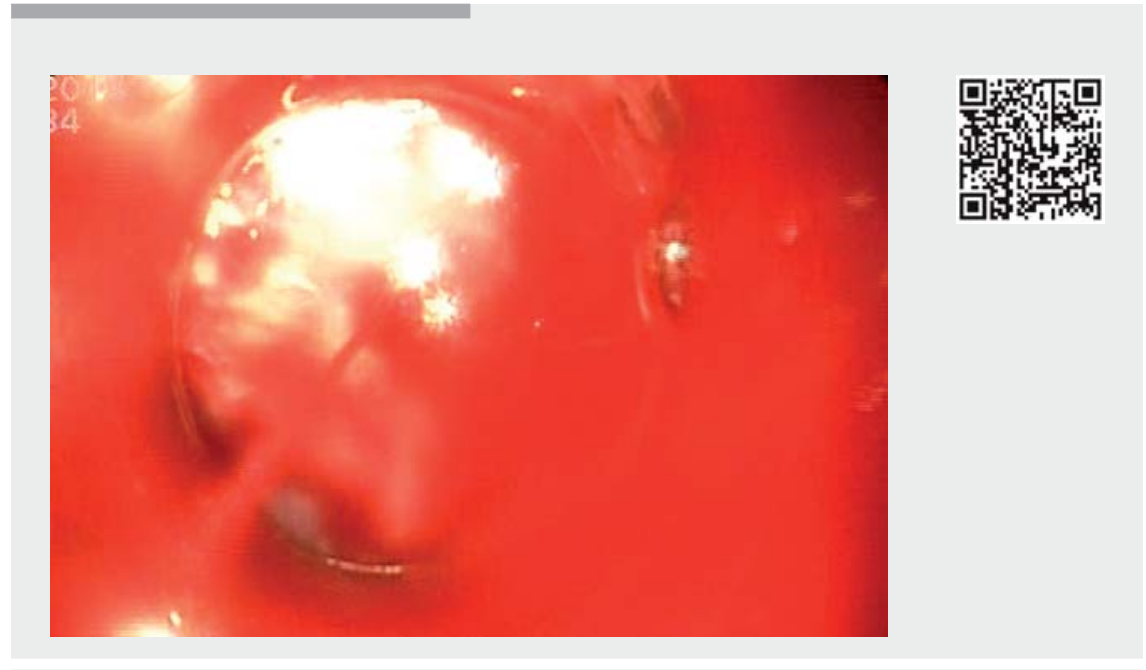

Video 1 A patient with a postbanding ulcer bleeding after initially successful therapy with transjugular intrahepatic portosystemic shunt. Hemostasis was achieved with the application of an over-the-scope clip. No acute rebleeding was observed after extensive irrigation with saline.

It should be noted that the use of OTSC in PBUB currently constitutes an off-label application. Hitherto, there is only one report known to us regarding the (off-label) use of OTSC in acute variceal bleeding [2].

Endoscopy_UCTN_Code_TTT_1AO_2AD

Competing interests

Drs. Caca and Schmidt have received lecture fees from Ovesco Endoscopy. The Department of Gastroenterology received a study grant for the "STING"-Study.
The Authors

Oscar Cahyadi ${ }^{1}$, Karel Caca ${ }^{1}$, Arthur Schmidt ${ }^{2}$

1 Department of Gastroenterology and Oncology, Klinikum Ludwigsburg, Ludwigsburg, Germany

2 Center of Interdisciplinary Gastrointestinal Endoscopy, University Medical Center Freiburg, Germany

\section{Corresponding author}

\section{Oscar Cahyadi, MD}

Medizinische Klinik I, Klinikum Ludwigsburg, Posilipostraße 4, 71640 Ludwigsburg,

Germany

Fax: +49-7141-9967219

oscar.cahyadi@kliniken-lb.de 


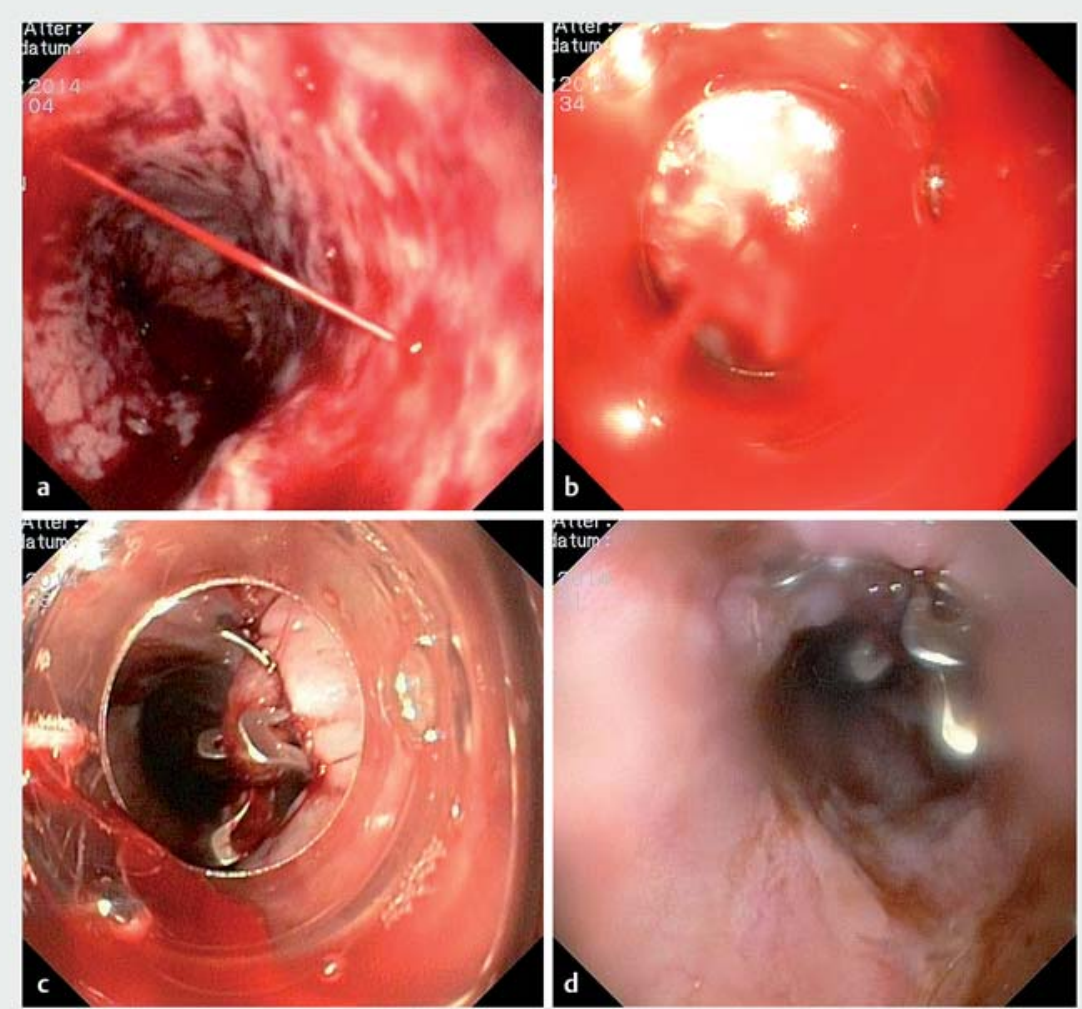

- Fig. 1 Application of an over-the-scope clip (OTSC) for postbanding ulcer bleeding. a Active spurting bleeding from a postbanding ulcer was seen. A second esophageal variceal band was not possible because of tissue scarring. An OTSC was thus chosen as therapy. $\mathbf{b}$ The bleeding source was positioned in the center of the OTSC applicator cap.c After deployment of the OTSC, the bleeding stopped immediately. $\mathbf{d}$ At second-look endoscopy, no sign of recurrent bleeding was seen.

\section{References}

[1] Tierney A, Toriz BE, Mian S et al. Interventions and outcomes of treatment of postbanding ulcer hemorrhage after endoscopic band ligation: a single-center case series. Gastrointest Endosc 2013; 77: 136-140

[2] Sharma R, Sethi A. The use of over-thescope-clips in acute variceal hemorrhage. Am J Gastroenterol 2017; 112: 208 - 208

\section{Bibliography}

DOI https://doi.org/10.1055/s-0043-115890

Published online: 31.7.2017

Endoscopy 2017; 49: E258-E259

(c) Georg Thieme Verlag KG

Stuttgart · New York

ISSN 0013-726X

\section{ENDOSCOPY E-VIDEOS}

https://eref.thieme.de/e-videos

回直 Endoscopy E-Videos is a free access online section, reporting 靣程: on interesting cases and new techniques in gastroenterological endoscopy. All papers include a high quality video and all contributions are freely accessible online.

This section has its own submission website at

https://mc.manuscriptcentral.com/e-videos 